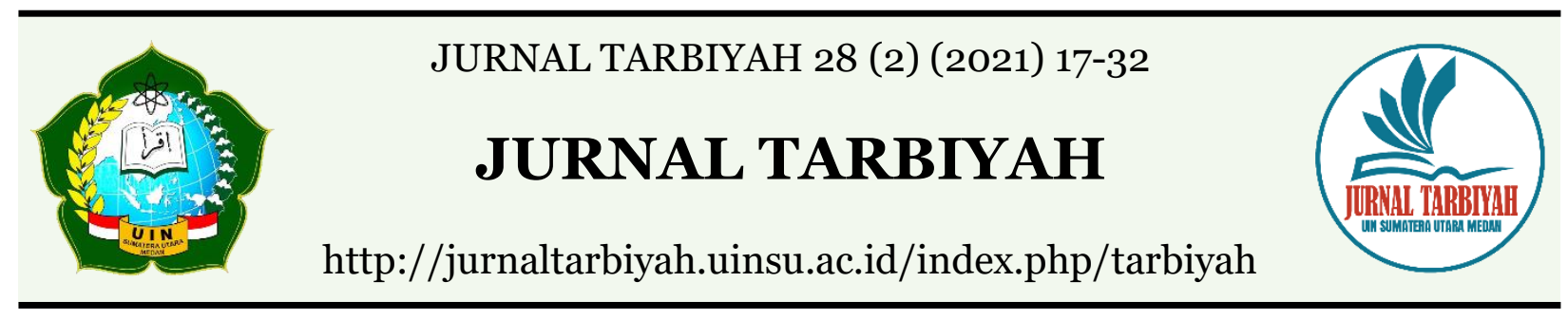

\title{
IMPROVING LOYALTY OF SCHOOL MANAGEMENT PERSONNEL THROUGH ORGANIZATIONAL COMMUNICATIONS APPROACH
}

\author{
Aini Safitri ${ }^{1}$, Heri Rahmatsyah Putra² \\ 1,2 STAIN Teungku Dirundeng Meulaboh \\ Email: ${ }^{1}$ aini.safitri@staindirundeng.ac.id \\ 2 herirahmatsyahputra@staindirundeng.ac.id
}

DOI : 10.30829/tar.v28i2.1108

Accepted: September 3oth, 2021. Approved: December 28th, 2021. Published: December 30 th, 2021

\begin{abstract}
Teachers and employees are the driving force in the management of school institutions. Successfully managing a school depends on the flow of information from each level. Communication as a human need plays a crucial role in increasing the loyalty of school residents. Leadership communication to subordinates and vice versa and communication between members is also expected to create a harmonious working atmosphere. This study aims to determine the efforts to increase the loyalty of school personnel through an organizational communication approach by school principals by applying qualitative research methods that describe in-depth what was obtained from the informant. The study results indicate that the form of organizational communication in increasing the loyalty of school residents takes place vertically and horizontally. The principal communicates openly or directly at ceremonies and meetings and personally to teachers and employees in instructing all kinds of policies and providing encouragement to improve the performance of teachers and employees. Likewise, between teachers and employees, there is horizontal communication that creates a harmonious and pleasant work environment to increase employee loyalty and motivation.
\end{abstract}

Keywords: Communication Organization, Loyality, School Management 


\section{INTRODUCTION}

Communication is something that cannot be avoided in human life. Therefore, it is necessary to build good communication to create harmonious relationships with other people in life. Likewise, in an organization, communication is the primary key in exchanging information between parts of the organization, both between leaders and members and members with fellow members in the organization. In organizational communication, communication problems consistently arise in organizational processes. Therefore, communication within the organization becomes a flow system that connects and generates performance between parts of the organization to produce synergies.

Communication is a process because it is a continuous series of activities, which has no beginning or end and is constantly changing. Communication also involves a complex variety of interconnectedness that can never be duplicated in the same way: the interrelationships among people, environments, skills, attitudes, statuses, experiences, and feelings, all of which determine the communication that takes place at any given time (Cangara, 2014:35). Communication-based on its scope is divided into several kinds, one of which is organizational communication. Organizational communication itself is communication built within an institution that plays a communication role, meaning that communication occurs from superiors to subordinates (vertical), fellow employees (horizontally), and so on. (Arni, 1995:66). The statement above emphasizes that organization is very important for human life. Because almost every aspect of life can not be separated from the so-called organization. Organizations are formed so that people can solve their problems and achieve goals by cooperating in an organization (Putra, 2020). In the world of education at Public Elementary School (SDN) 024 Bangko Mukti Riau, competition for quality and quality and realizing the vision and mission of each elementary school is unavoidable. Employees (management) of the school plays an essential role in quality and quality competition and realize the institution's vision and mission. Employees become one of the fundamental driving forces in advancing the institution so that the school can grow. Employees who are loyal in their work and can be relied on to work with dedication make a vital contribution to the success achieved by the agency.

In education management, good communication is needed in managing educational institutions. Communication is a significant activity in the organization. The results of a communication expert's research concluded that leaders and managers use about $75 \%-90 \%$ of their working time to communicate. If two or more people work 
together, there needs to be communication between them: the better a person's communication, the better possible cooperation with others. Effective communication requires mutual respect, trust, openness, and responsibility. The leader or, in this case, the principal conveys all management functions and management tasks through communication channels. The principal plans, organizes, implements, and controls, communicating to his subordinates. Likewise, administrative tasks such as students, teaching and educational staff, finance, facilities and infrastructure, school relations with the community, and special services are also carried out through communication. Leadership is translated into terms of traits, personal behavior, influence on others, patterns of interaction, cooperative relationships between roles, an administrative position, and perceptions of others about the legitimacy of influence. These different definitions contain common assumptions that are general. One group phenomenon involves interaction between two or more people. In involving the influencing process, where the leader deliberately uses influence on subordinates (Wahjosumijo, 1999:16). However, sometimes the problem of inequality in the flow of information regarding each personnel's policies and main tasks often occurs in an organization, especially an organization or educational institution that sometimes encounters obstacles or misdirections. Things like this can also trigger the loyalty of members or school personnel to decrease. It is where the role of the principal as a leader becomes a mediator or organizer of good relations between personnel. The low loyalty of school personnel is also indicated by the number of personnel members who arrive late; some rarely attend school.

Several previous studies are relevant to this research. Research conducted by Hidayati reveals that influential educational leaders must make the people they lead, especially educators and educational staff aware, that good quality education does not always have to be expensive. With sincerity, tenacity, and good teamwork, all goals can be achieved, especially the qualification standards of educators and education staff can be met and achieved, and their sustainability is maintained. Educational leaders have the responsibility to create an organizational culture and a conducive climate for efforts to increase growth and enhance the development of educational institutions following the required quality standards. In this regard, educational leaders have three prominent roles: leadership, managerial, and educational fields for all elements of the institution (Ginting \& Haryati, 2012). The research also focuses on the leadership of an educational institution leader in improving the quality of education. In addition, there is also research 
conducted by Sermal; the results of his research should be leaders, especially leaders in the field of education, in carrying out their leadership activities in influencing their subordinates based on sound leadership criteria. Then in making an educational program, leaders should understand the circumstances or abilities possessed by their subordinates and divide assignments according to their respective abilities. Leaders must be able to understand their duties as a leader. In addition, in carrying out their activities, both leaders and those led establish a cooperative relationship that supports each other to achieve organizational or agency goals. (Sermal, 2015).

\section{LITERATURE REVIEW}

1. Improving Loyality

Loyalty is a willingness to cooperate, which means a willingness to sacrifice oneself, exercise self-control, and highlight one's interests. This willingness to sacrifice oneself involves awareness to devote oneself to an institution (Suwardi, 2015). Loyalty comes from the word loyal, which means loyal. Loyalty within the company can be interpreted as an employee's loyalty. Velasques said that employees must work well to achieve company goals and avoid activities that can threaten or interfere with achieving these goals and not for the personal interests or benefits of employees. The thing that can cause difficulties in the realization of loyalty is a conflict of interest, namely a conflict between the personal interests of employees and the interests of the institution. For the sake of personal interest, employees may not carry out activities that compete with their company. In addition, conflicts of interest can also arise by combining several types of work. According to Sudimin, loyalty means the willingness of employees with all abilities, skills, thoughts, and time to participate in achieving company goals and keeping company secrets, and not taking actions that harm the company as long as that person is still an employee. Except keeping a secret, these things can only be done when a working relationship with the company still binds the employee. Fletcher defines loyalty as loyalty to someone and not leaving or defecting and not betraying others when needed (Frestiawan, 2018). A teacher must meet two categories concerning education: capability and loyalty. Capability: The teacher must have the ability in the science field and have good theoretical abilities about teaching, from planning, implementation to evaluation. Teacher loyalty, namely being loyal to the teacher's duties, not only in the classroom but also outside the classroom (Suwardi, 2015). 
In realizing employee loyalty, it is necessary to have a good relationship between the agency/organization members built through an effective communication process. Effective communication can be done by using communication techniques. The effective speaking technique is speaking interestingly and clearly so that it can be understood and achieve the expected goals in communication. The technique of speaking in communication must adapt between the communicator and the communicant to the message being discussed. Communication techniques are used so that communication between humans is established effectively. The definition of technique is a method used to do something. While the notion of communication is the delivery of information from communicators to communicants through certain media (Rahman, 2000:34).

\section{Educational Management (School)}

Management is an effort or action towards achieving goals, a cooperative system, and optimally involving people, funds, physical and other resources. In education, management is the activity of combining educational resources to concentrate on achieving predetermined educational goals. Educational management is the process of developing the activities of groups of people to achieve the educational goals that have been set. Educational input is everything that must be available because it is needed for its survival. Something, in this case, are resources, tools, and expectations as guides for the ongoing process, a) human resources (HR), namely madrasa principals, teachers, learning resources, students, employees, security, and resources, the rest is equipment, equipment, money, materials, etc.) The tools include the school's organizational structure, laws and regulations, job descriptions, plans, programs, etc.) While the expectations are in the form of vision, mission, goals, and objectives to be achieved by the institution.

Education is adults' conscious and responsible effort in guiding, leading, and directing humans with various problems or problems and questions that may arise in its implementation. So, education as a process can be interpreted as changing human behavior into adults so that they can live independently and as members of society in the natural environment where the individual is located. UU RI No. 20 of 2003 states that education is a conscious and planned effort to create a learning atmosphere and learning process so that students actively develop their potential to have religious, spiritual strength, self-control, personality, intelligence, noble character, and skills that are needed by himself, society, nation, and state (Syaiful Sagala, 2015). 
In micro-scale education (school level), the educational process is the decisionmaking process, the institutional management process, the program management process, the teaching and learning process, and the monitoring and evaluation process. The process is said to be of high quality if the coordination and harmonization of the integration of madrasah inputs (teachers, students, money, curriculum, equipment) are carried out in harmony, thus creating a learning situation that can encourage motivation to learn and empower students not only to master knowledge. This knowledge is also a charge of the conscience of students, internalized, practiced in everyday life, and more importantly, able to develop themselves. The output (output) of education is the performance of the madrasa. This performance can be measured by its quality, effectiveness, efficiency, innovation, quality of work-life, and morale. Output can be said to be of high quality if the student's achievement shows high achievement in 1) academic achievement; general test scores, UAN, scientific works, academic competitions; 2) nonacademic achievements, such as faith in piety, honesty, decency, sports, arts, and other extra-curricular activities (Murni, 2016).

The success of an educational institution is highly dependent on the principal's leadership. Because the principal, as a leader in his institution, must be able to bring the institution towards achieving the goals that have been set, must be able to see changes, and see the future in a better-globalized life. The principal must be responsible for the smoothness and success of all arrangements and management affairs formally to his superiors or informally to the community entrusted to their students. Principals are formal leaders in educational institutions. It is interpreted as the principal because the principal is the highest official in the school. The principal is the main structural and administratively responsible for the school. Therefore, the principal has staff or officials under his leadership (Sulistiyorini, 2009:133).

It needs to be considered because every school generally has dreams and aspirations to become the organizer of a quality education process to support national education goals, namely the nation's intellectual life. Widodo stated that the education process involves various inputs, namely: teaching materials, methodologies, school facilities, administrative support, other facilities, and infrastructure, as well as a conducive environment. Furthermore, school management must synchronize these various inputs to create schools with quality services. Based on this opinion, administrative support, which is a variety of office activities, needs to be considered in its management so that it can contribute well to school services (Siregar,2017). 
Effective principals act as leaders who can move people and encourage organizations to develop to achieve excellence-acting as a manager in charge of ensuring that learning takes place effectively and measuring the results achieved to be used as a reference for quality improvements later. Leadership is an essential part of an organization. Leadership is an action taken by individuals or groups to coordinate and provide direction and guide and influence other individuals or groups who are members of an organization to achieve predetermined goals. The success of a leader can be seen from the nature and behavior of a leader. Leadership behavior will give birth to leadership styles according to the abilities, conditions, and situations of the leader and the people being led (Fadhli, 2016).

\section{Organizational Communication}

At first, the study of communication, let alone the science of communication, was something that had never existed in the treasury of science. When at first all human problems were still in the study of philosophy, then communication was not thought of or thought of by humans (latent phenomena). At this time, the science of communication began to develop rapidly in the realm of social science (Mulyana, 2007:46). The seller provides an understanding of communication; namely, communication is a process by which verbal and nonverbal symbols are sent, received, and given meaning (Arni, 2015:4). Thus, if you look at the understanding conveyed by Williams J. Seller, the communication process is straightforward, which is only the process of sending and receiving messages. However, communication is a complex phenomenon that is difficult to understand without knowing the critical principles and components of communication. In Islam, as the source of all knowledge, the Qur'an has explained a lot about communication. If in Islamic communication science, it can be understood that communication in Arabic is known as al-ittisal, which comes from the root word wasola, which means to convey. Hussain defines Islamic communication as a process of conveying messages or information from the communicator to the communicant by using the principles and methods of communication contained in the Qur'an and Hadith. Thus, in theoretical and practical aspects, Islamic communication can be different from communication according to the perspective of general communication because Islamic communication is based on the Qur'an and Hadith, which upholds the truth. In contrast, general communication prioritizes political and material gains (Kholil, 2007:2). 
Organizations are associations, cooperative groups between people held to achieve common goals, the composition, and rules of various organs, and so on to be an orderly unit. The organization is also a place where management activities are carried out. As a forum for the basic pattern of organizational structure, it is relatively permanent, meaning that the organizational structure is not changed intermittently (Arni, 2011:3). Human interaction in an organization is a must. An organization cannot run well without interaction from its members. The interaction of members of the organization can only be carried out with the existence of communication. The correlation between communication science and organization lies in its review, which focuses on the people involved in achieving organizational goals. Communication science questions what forms of communication occur in organizations, what organizational methods and techniques are used, what media is used, how the process is, what factors are the obstacles, and so on. The answers to these questions are for study material and then present a communication concept for an organization by considering the particular situation at which communication takes place.

Organizational communication is sending and receiving various organizational messages within the formal and informal groups of an organization. Formal communication is approved by the organization itself and is oriented to the interests of the organization. The contents can be in the form of ways of working in the organization, productivity, and various jobs that must be done. For example, policy memos, statements, press conferences, and official letters. Informal communication is a socially approved process. The orientation is not to the organization but rather to individual members. In other words, organizational communication is a process of creating and exchanging messages in a network of interdependent relationships to cope with an uncertain or changing environment (Wursanto, 2003:34).

The purpose of communication in the organizational process is none other than in order to establish mutual understanding (mutual understanding). In short, there should be equality in terms of reference and the field of experience. Although it is almost impossible to equate the cognitive domains of individuals in an organization, through planned communication activities and the substance is designed, at least there is a process of diffusion (diffusion) of organizational dimensions to everyone. Three approaches can be used to see communication in an organization, macro, micro, and individual (Arni, 2015: 30). 


\section{RESEARCH METHOD}

This study used the descriptive qualitative method. Qualitative research is research that can explain and analyze phenomena, events, social activities, attitudes, beliefs, perceptions of a person or group of things (Hamdi, 2014:9). This study prioritizes direct data so that the researchers themselves go into the field to conduct observations and interviews with school structural employees regarding efforts to increase the loyalty of school personnel through an organizational communication approach at SDN 024 Bangko Mukti Riau.

\section{RESULT AND DISCUSSION}

Conflict is a daily situation faced in school management. When there is conflict, there are usually differences in thinking and feeling. The real issue in conflict is not the perception of who is right and who is wrong, but the real issue is how to deal with the diversity of thought patterns and feelings. Disagreements in conflict and the relationship between conflict and change provide positive input for school managers to improve the climate in the schools they lead (Anzizhan. 2015). Organizational communication climate can be realized by the existence of a good and effective communication process between organization members. In general, the communication conveyed by the communicator has a significant influence on the communicant. Both positive and negative influences, depending on the response of the communicant. An institution in general also wants a positive influence on the communication they run (Putra, 2020). Effective communication within the organization is needed to minimize friction that causes conflict, to create a climate of organizational communication conducive to achieving the organization's goals.

1. Top-down Communication

In simple terms, transforming information from managers at all levels to the bottom is a communication from top to bottom (top-down or downward communications). The flow of communication from managers to subordinates is generally related to their responsibilities and authorities in an organization. A manager who uses downward communication lines aims to convey information, direct, coordinate, motivate, lead, and control various activities at lower levels. The communication line that comes from the top (manager) to the bottom (employee) is the delivery of messages that can be in the form of orders, instructions, or procedures to be carried out by subordinates as well as possible. (Handoko, 1998:280). It is necessary to pay attention to using the 
same language, simple, not long-winded, and easy to understand in delivering messages to achieve the desired goal. For example, the delivery of messages from the general manager (general manager) to the production manager, then to the factory, then only to the employees using a communication channel that is quite long and has the potential to cause communication misunderstandings (Heri, 2019).

Top-down communication can be in the form of oral or written. Oral communication can be in the form of regular conversations, formal interviews between supervisors and employees, or can also be in the form of group meetings/discussions. In addition, written communication can also be in memos, training manuals, information boxes, letters of assignment, warrants, decrees, letters of dismissal/dismissal, bulletin boards, and manuals for employee duties (Purwanto, 2006:41). The primary purpose of downward communication is to provide direction, information, instructions, advice or suggestions, and assessments to subordinates and provide information to members of the organization about the goals and policies.

It is necessary to pay attention to using the same language, simple, not longwinded, and easy to understand in delivering messages to achieve the desired goal. For example, the delivery of messages from the general manager to the production manager, then to the factory, then only to the employees uses a reasonably long communication channel and can cause misunderstandings. In general, downward communication can be classified into five types, namely:

1) Task Instructions are messages conveyed to subordinates about what they are expected to do and how to do it.

2) Rational. Work rationale is a message that explains the purpose of the activity and how the activity relates to other activities in the organization or organizational objectives.

3) Ideology. The message about this ideology is an extension of the rational message. In the rational message, the emphasis is on task descriptions and their relation to organizational perspectives. While the ideological message, on the other hand, the ideological message seeks to support and enthusiasm from organizational members to strengthen loyalty, morale, and motivation.

4) Information. Information messages are intended to acquaint subordinates with organizational practices, rules, benefits, habits, and other data unrelated to instruction and rationale. 
5) Flip. Feedback is a message that contains information about the individual's accuracy in doing his job. One simple form of this feedback is the payment of salaries of employees who are ready to do their jobs, meaning the work is satisfactory (Arni, 2015:108).

Responses from informants regarding communication from the principal (principal) to subordinates in increasing loyalty are as follows;

"Principal of SDN 024 Bangko Mukti: With the establishment of an exemplary communication process, the exchange of information from the principal to teachers and employees goes smoothly. The communication process tends to use vertical communication and sometimes uses horizontal communication. Vertical communication seems to be used more effectively because principals and teachers can openly communicate everything related to work. Vertical communication also makes it easier for teachers to convey their opinions to the principal. The principal conveys information to the teacher concerned with the work carried out; then, the teacher will inform other teachers. The principal also often provides information through the morning ceremony held every Monday. I indeed communicate according to the level, but sometimes I go straight to the teacher concerned with an urgent need. Communication with teachers and staff at this school is like family and open. I hold meetings every three months to evaluate my work. Not only that, but I also often use the morning ceremony to convey messages to teachers and employees. It is not uncommon to go directly to subordinates to control the work of subordinates. The form of organizational communication in this school is that information from the principal will be conveyed to the respective field teacher and homeroom teacher only after it is informed to other subordinates. In my opinion, the principal must be open, firm, and disciplined.

The teacher in the field of the study said: The principal has an open way of communicating, where the principal will call the teacher concerned to convey a particular message and provide direction to motivate teachers and employees here. In addition, the principal also interacts with teachers and employees by holding meetings to convey motivation to their subordinates. Teachers in other fields of study also said that the leadership at SDN o24 Bangko Mukti, in conveying information, uses vertical communication from top to bottom where the principal will directly call the teacher concerned with the work to be delivered. If there is an urgent matter, the principal will also go directly to study teachers and homeroom teachers to other structural employees. 
In this case, the form of communication used between school principals and teachers to increase work motivation is vertical communication, communication from top to bottom and from bottom to top, namely from leadership to subordinates and from bottom to leadership reciprocally. In motivating vertically, the principal provides instructions, information, explanations, and others to teachers and structural employees. On the other hand, teachers also provide reports, suggestions, complaints, and the principal. The principal always communicates everything related to the problems at SDN 024 openly by holding meetings and conveying messages through morning ceremonies. It is very effective to use because teachers and employees know the information conveyed by the principal. The principal also goes directly to control the work of teachers and employees.

\section{Horizontal Communication}

Horizontal communication (horizontal communications), or literal communication (lateral communications), occurs between parts that have parallel or equal positions in an organization. The purpose of horizontal communication, among others, is to persuade, influence, and provide information to sections or departments that have equal positions. This form of communication is coordinating and results from the concept of organizational specialization.

So that this communication is designed to facilitate coordination and problemsolving, horizontal (lateral) communication and assisting lateral activities also avoid slow problem-solving procedures. Horizontal communication has a specific purpose, including coordinating tasks; the heads of sections in an organization sometimes need to hold meetings or meetings to discuss how each section contributes to achieving organizational goals. Then share information for planning and activities. Many people's ideas are usually better than the ideas of one person. Moreover, it can solve problems that arise between people at the same level.

Resolve conflicts between members within the organization and sections with other sections. Guarantee the same understanding. When a change in an organization is proposed, it needs to be a common understanding between organizational units and members of an organizational unit about the change. Develop interpersonal support. Because most of the working time employees interact with their friends, they get interpersonal relationship support from their friends.

In practice, there is a tendency that in carrying out their work, managers like to exchange information with their colleagues in different departments or divisions, 
especially when unique problems arise in a company organization. Horizontal communication is coordinated among those with equal positions, both within one department or between several departments. Horizontal communication becomes important when every part or department in an organization has a relatively significant level of interdependence. However, if each part can work independently without having to depend on other parts, horizontal communication is not often or minimally used. The informal network structure is to have a minimum of linkages among group members. The selection, encoding, and decoding processes must be repeated for each link path. So with the addition of each link line, the possibility of semantic distortion occurs, and communication problems multiply.

Informal communication causes personal information to emerge from interactions among people and flow throughout the organization unpredictably. This communication network is better known as rumors (grapevine) or Kabarangin. The information flowing in this grapevine network seems to be fluid and hidden. In communication terms, the grapevine is a method of passing on secrets from person to person, which is not obtained through formal communication networks. Informal communications contain confidential reports of people and events that do not flow officially. Information from hearsay relates to what is heard or what people are saying and not what is announced by those in power. Apart from the vertical communication carried out by the principal, teachers, and employees of SDN 024, it is also effective in carrying out horizontal communication between fellow teachers and employees for the smooth flow of information within the school. Fellow teachers at SDN 024 Bangko Mukti always coordinate regarding policies handed down by the principal. From the results of the interviews, the research informants explained: establishing good relations by communicating with fellow teachers should indeed be done for the smooth running of work and the harmony of the school environment. At the homeroom level, we always communicate about work, even though we take care of our respective classes." Study teacher Erni Yusnita added that, "to achieve maximum work results, fellow teachers must form a synergistic relationship, in the sense of communicating and supporting each other in order to achieve common goals. I think the communication that has taken place so far is not only about work, but we often talk about things outside of school. However, we do this to establish friendship and strengthen cohesiveness at the teacher level."

Administrative Officer Syafrizal: "My view of the communication that has taken place at school so far is very stable; although the father (head of school) is busy, he always 
takes the time to communicate directly with his subordinates. However, the most important thing is that the communication between teachers and employees goes smoothly. Because at our level, there are very few formal situations that seem rigid. We always communicate about performance or not. Most importantly, professionalism must be maintained. With this kind of communication, I feel I can build a good relationship which increases my motivation and personal performance."

From the findings above, the researchers analyzed that apart from vertical communication, horizontal communication between teachers and employees at SDN 024 Bangko Mukti is also a driving force for creating a harmonious work environment to motivate them to improve their performance at the school. A smooth flow of information and open relationships between individuals (teachers) will create a healthy organizational communication climate. A healthy communication climate with firmness and openness makes it possible to achieve a common goal that an organization or agency has aspired to. Because with this kind of communication, employees will feel happy and appreciated by their superiors, so they are more motivated to work.

\section{CONCLUSION}

The form of organizational communication that occurs at SDN 024 Bangko Mukti to increase the loyalty of school personnel takes place vertically and horizontally. Vertical communication from the principal occurs openly by directly calling the teachers and employees (subordinates) concerned regarding internal policies, and sometimes it is also conveyed openly in ceremonial activities and meetings to motivate teachers and employees to improve performance. Organizational communication at SDN 024 Bangko Mukti also occurs horizontally between fellow teachers and employees. Communication takes place in formal and informal situations to create a pleasant working atmosphere to improve performance at the subordinate level. An excellent organizational climate or atmosphere will significantly affect the smooth flow of information and emotional relationships among teachers and employees at SDN 024 Bangko Mukti Riau.

\section{REFERENCES}

Cangara, Hafied, 2014.Perencanaan dan Strategi Komunikasi, Jakarta: PT Raja Grafindo Persada.

Suwardi, Masni, Fitrin, Pengaruh Loyalitas Terhadap Kinerja Guru SD Awal, Jurnal ALAZHAR INDONESIA SERI HUMANIORA, Vol .3, No. 1, Maret 2015 
Frestiawan Noringgar Jaya, Pengaruh Keadilan Prosedural, Gaya Kepemimpinan Transformasional Dan Motivasi Kerja Terhadap Loyalitas Karyawan, Jurnal Ekobis Dewantara Vol. 1 No. 11 November 2018

Rahman, Gazali, 2000. Teori Organisasi dan Komunikasi, Makassar: Universitas Hasanuddin.

Handoko,T. Hani, 1998. Manajemen, edisi ke-2, Yoyakarta: BPFE-Yogyakarta.

Purwanto,Djoko, 2006. Komunikasi Bisnis, Edisi ketiga, Jakarta: Erlangga.

Hamdi Asep Saepul, Baharuddin E, 2014. Metode Penelitian Kuantitatif Aplikasi Dalam Pendidikan, Yogyakarta: Budi Utama.

Effendy, Onong Uchjana, 2004. Ilmu Komunikasi; Teori dan Praktek, Bandung: PT. Remaja Rosdakarya.

Kholil, Syukur, 2007. Komunikasi Islam, Bandung: Cipta Pustaka Media.

Muhammad, Arni, 2015. Komunikasi Organisasi, Jakarta: BumiAksara.

Muhammad, Arni, 2011. Dasar-dasar Organisasi. Jogjakarta: UUI Press Jogjakarta.

Mulyana, Deddy, 2007. Ilmu Komunikasi Suatu Pengantar, Bandung: Remaja Rosdakarya.

Susanto, Sosiologi Komunikasi, cetakan ke-3, Jakarta: Kencana Prenada Media Group, 2008.

Siregar, Fauzan Ahmad. Implementasi Manajemen Perkantoran Modern di Sekolah MAS Amaliyah Sunggal, JURNAL TARBIYAH, Vol. 24, No. 2, Juli-Desember 2017.

Anzizhan, Konflik Dalam Organisasi Sekolah, JURNAL TARBIYAH, Vol. 22, No. 1, Januari-Juni 2015.

Fadhli, Muhammad. Kepemimpinan Kepala Sekolah Yang Efektif Dalam Menciptakan Sekolah Efektif, JURNAL TARBIYAH, Vol. 23, No. 1, Januari-Juni 2016

Ginting, R., \& Haryati, T. (2012). Kepemimpinan dan Konteks Peningkatan Mutu Pendidikan. Jurnal Ilmiah CIVIS, II(2), 1-17.

Putra, H. R. (2020a). Bentuk Komunikasi Organisasi Di Jurusan Komunikasi Dan Penyiaran Islam Uin Ar-Raniry Banda Aceh. SOURCE : Jurnal Ilmu Komunikasi, 5(2), 68-79. https://doi.org/10.35308/source.v5i2.1714

Putra, H. R. (2020b). Komunikasi Dalam Membentuk Iklim Organisasi Di Lingkungan Kampus Universitas Islam Negeri (Uin) Ar-Raniry Banda Aceh. At-Tanzir: Jurnal Ilmiah Prodi Komunikasi Penyiaran Islam, 63. https://doi.org/10.47498/tanzir.v11i1.352

Sermal. (2015). Kepemimpinan Pendidikan Untuk Mengembangkan Sekolah Bermutu. 
Aini Safitri, Heri Rahmatsyah Putra / JURNAL TARBIYAH 28 (2) (2021) 17-32

Jurnal Tarbiyah, 22(2), 243-260.

Syaiful Sagala. (2015). Manajemen dan kepemimpinan pendidikan pondok pesantren. Jurnal Tarbiyah, 22(2), 205-225. 